\title{
Bird communities at two marshes in Øvre Forra, today and 40
} years ago

\author{
Per Gustav Thingstad
}

Norwegian University of Science and Technology, University Museum, N-7491 Trondheim, Norway;

e-mail: per.thingstad@ntnu.no

\begin{abstract}
In the protected area Øvre Forra in Central Norway, birds were surveyed at two marshes in two succeeding years at the beginning of the 1970s. By following the same survey procedure 40 years later in these unchanged marsh habitats, I sought changes in the breeding bird community. While the total number of waders seems to have been quite stable, the abundance of some of the involved species might have changed during this period of time. Due to low numbers, and annual variations, the implications for some of the involved species have to be taken cautiously. The most abundant species in Øvre Forra is now the Common Redshank Tringa totanus. This species has outnumbered the earlier most abundant species in this bird community, the Meadow Pipit Anthus pratensis. The numbers of the Meadow Pipit, Northern Lapwing Vanellus vanellus, European Golden Plover Pluvialis apricaria and Common Sandpiper Actitis hypoleucos all tend to be lower than for 40 years ago. The Common Gull Larus canus and two Tringa species, the Common Redshank T. totanus and Common Greenshank T. nebularia, seem to have increased in numbers, while the situation for the Common Snipe Gallinago gallinago and the Whimbrel Numenius phaeopus appears to be stable. The Ruff Calidris pugnax used to be a characteristic species on the Øvre Forra's bogs in the 1970s, but has since vanished. Altogether, the study shows an apparently quite stable avifauna over the time span of 40 years in this environmentally stable reserve.
\end{abstract}

Key words: Marshes; bird densities; long-term population changes

\section{INTRODUCTION}

Many ornithological publications have documented changes in terrestrial bird populations over the last decades. However, very few Fennoscandian surveys have been conducted continuously since the 1960/1970s; exceptions being the work at Ammarnäs in southern Swedish Lapland (cf. Enemar et al. 2004, Svensson \& Andersson 2013) and in Budalen in central Norway (Hogstad 2005, Thingstad et al. 2015). An alternative approach is to repeat surveys carried out some decades ago using standardized methods. Changes in the actual bird community can then be sought by following the same procedure in the same survey plots some decades later (e.g. Lawicki et al. 2011, Byrkjedal \& Kålås 2012, Hardeng 2014, Grund 2014).

Many European long-distance migrants, among those many waders, have declined significantly since the 1960s (Tucker \& Heath 1994, Birdlife International 2004, Zwarts et al. 2010), for some species attributable to the drought period in the African Sahel region that started at the beginning of the 1970s and lasted for more than two decades (e.g. Peach et al. 1991, Foppen \& Reijnen 1996, Zwartz et al. 2010). A largescale annual bird population monitoring project, the Norwegian Extensive monitoring of terrestrial birds initiated in 1996 (Kålås et al. 2014), started too late to register declines going back to before the 1990s. To get an idea about possible population changes during longer time-spans the alternative, which involves repeating published standardized past ornithological surveys closely today, can be used. By combining the result from a sufficient number of such studies one can look for long-term changes that otherwise can remain unnoticed even for species that are dispersed and in low abundance. The result from such an approach is given here, using ornithological surveys from two marshes in Øvre Forra in Central Norway in 1971 and 1972 (Moksnes 1977) as a reference material.

\section{STUDY AREA AND METHODS}

The survey area was within the Norwegian nature reserve and Ramsar site Øvre Forra in the Levanger, Verdal, Meråker and Stjørdal municipalities, NordTrøndelag (Figure 1). The actual plots were laid out and monitored by Moksnes in the early 1970s (Moksnes 1971, 1973, 1977). Identified from details on the original map (small creeks and pools in the bogs were used as references) the exactly same plots could be surveyed 40 years later (Thingstad 2012).

The two surveyed plots (I and II in Figure 1) included ombrotrophic bogs with string fens and open 


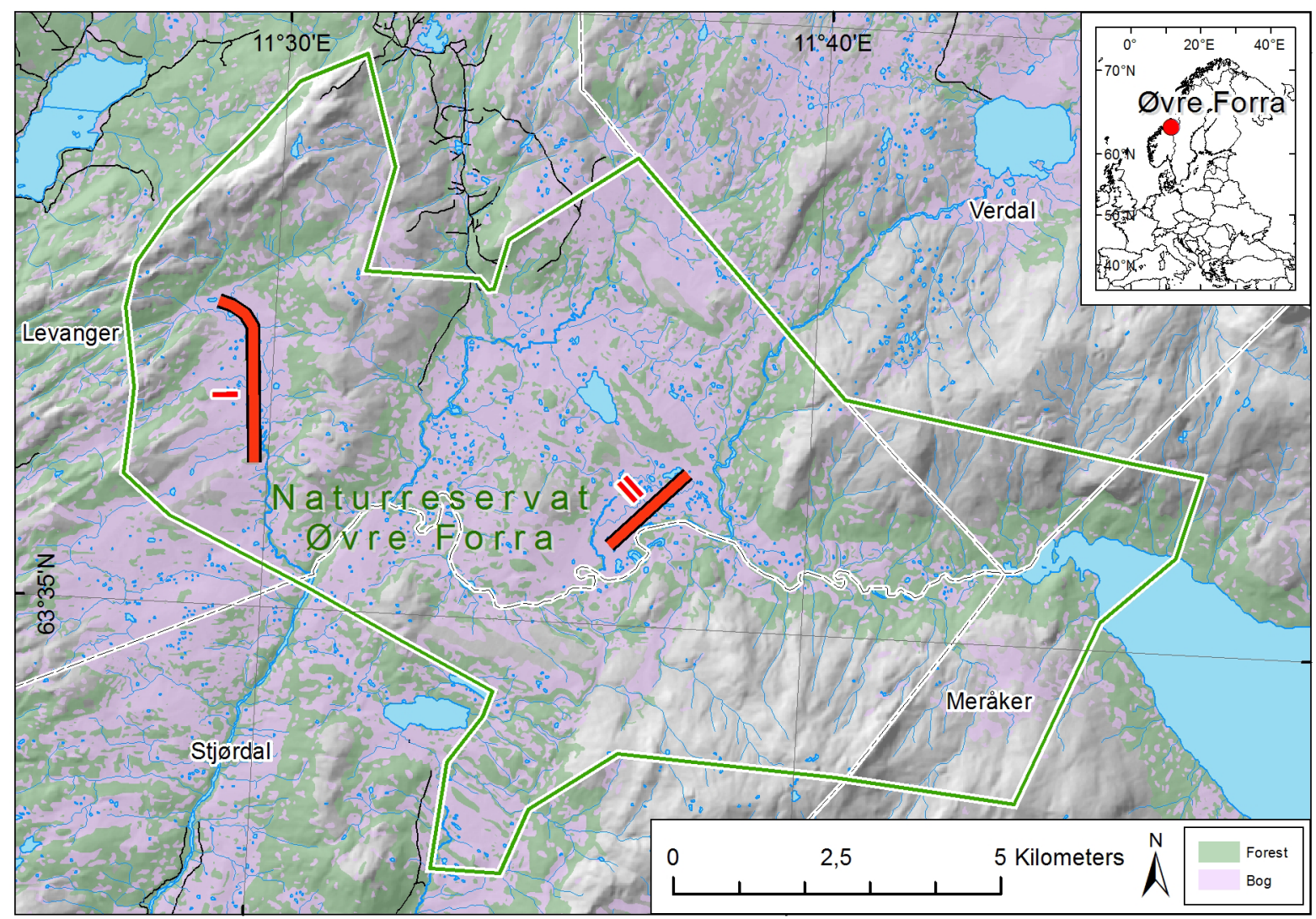

Figure 1. Map showing the reserve Øvre Forra with the two surveyed bog plots: $\mathrm{I}=$ Leinsslettene, II = Skillingsmyrin. Drawn after Moksnes (1977).

waters and flat fens with smaller, richer parts, and were $400-450 \mathrm{~m}$ a.s.l. Plot I at Leinslettene was 3000 x $200 \mathrm{~m}$ and plot II at Skillingsmyrin 1700 x $200 \mathrm{~m}$, thus totally covering $0.94 \mathrm{~km}^{2}$. There were no apparent changes in the physical habitat features of these boggy areas over the intervening four decades (Figure 2). While all of the Skillingsmyrin plot was on an open bog (alternating between small ponds, ombrotrophic bog and poor fen), some birch trees (Betula sp.) and willow scrub (Salix sp.) grew along the border of the Leinsslettene plot, which consists of small ponds, open poor and intermediate fen with small plots of damp Calluna heath (Moen et al. 1976) (Figure 3).

Although Svensson (1978) claimed that three censuses per year should be sufficient to monitor the territories of the "easy inventory species" on bogs, and five for the "middle easy inventory species", we used, as Moksnes (1977) did, the standard 10-census procedure of the "mapping method". This was essential to achieve comparable datasets. Furthermore, it reduced the risk of overseeing the more cryptic wader species, as well as allowing us to estimate numbers of passerine territories using the standard procedure for the mapping method. The surveys were conducted from the last days of May to late June, after snowmelt, in accordance with international recommendations for the standardized territory mapping method (10 censuses, mainly in early morning dispersed over some time to cover the different phases of the breeding season, cf. Bibby et al. 1992). As the individual territories (a cluster consisting of at least three records) for the involved waders may be large in relation to the surface cover of the surveyed area, some territories were not completely within the plots. In addition, the shape of the plots causes some substantial edge effects due to their restricted width. Accordingly, "border territories" were recorded as the fraction $(1 / 4,1 / 2$ and $3 / 4)$ of the cluster that fell within the surveyed area. Only individuals with territorial behaviour were recorded. However, also nests or nesting birds discovered within the plots were registered as territories (e.g. the criteria used for the Common Gull Larus canus). In some cases, as for the polygynous and lek-performing Great Snipe Gallinago media and Ruff Calidris pugnax, the mapping method is not very suitable, and the former birds within "fixed" day resting places, might have been incorrectly judged as territorial in 2011. With regard to the Ruff, only distracting females or a nest discovery were used as criteria (Arne Moksnes pers. medd.).

Due to few registered territories of the involved species (Table 1), few statistically significant differences between the two survey periods can be expected. Number of mapped territories was compared between the dyads $(1971+1972$ vs. $2011+2012)$ for the most numerous species, using chi-square tests (Fowler \& Cohen 1990). 

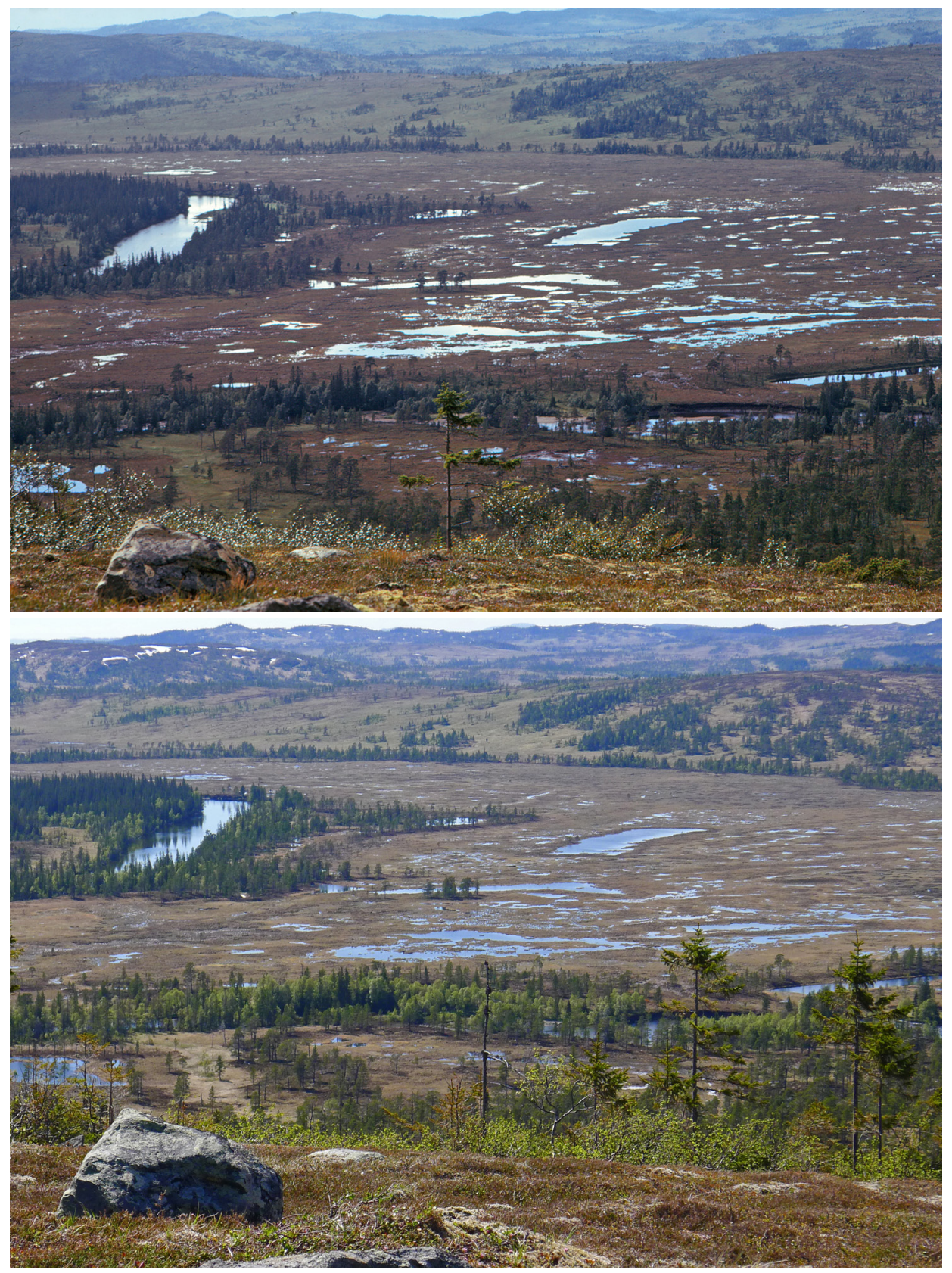

Figure 2. Skillingsmyrin as this area appeared at the beginning of the 1970s (upper picture) and in 2012 (lower picture), seen above from Færsvola in the south. The survey plot Skillingsmyrin (cf. Figure 1) goes right across the central parts of this bog. Photo: Per Gustav Thingstad.

\section{RESULTS}

A comparison of the total registered territories in the beginning of the 1970s with those from the beginning of the 2010s, shows evidence of few changes (Table 1). Altogether 16 species were recorded with breeding territories and, while five of these were passerines and one a gull, no less than 10 were waders. The most common species were Meadow Pipit Anthus pratensis, Common Redshank Tringa totanus, European Golden Plover Pluvialis apricaria and Whimbrel Numenius phaeopus, but only the two first mentioned were represented with more than 10 territories in any one year. Variation between years was tested for these two species, but the tests gave no statistically significant results (Meadow Pipit: $\chi^{2}=3.467, \mathrm{df}=3,0.5>\mathrm{p}>$ 0.25; Common Redshank: $\chi^{2}=1.270, \mathrm{df}=3 ; 0.75>\mathrm{p}$ $>0.50)$.

In 11 of the species the differences between years within dyads surmounted (or equalled) the difference between the dyads. Two species recorded in 1971 and 1972, Ruff and Northern Lapwing Vanellus vanellus, 


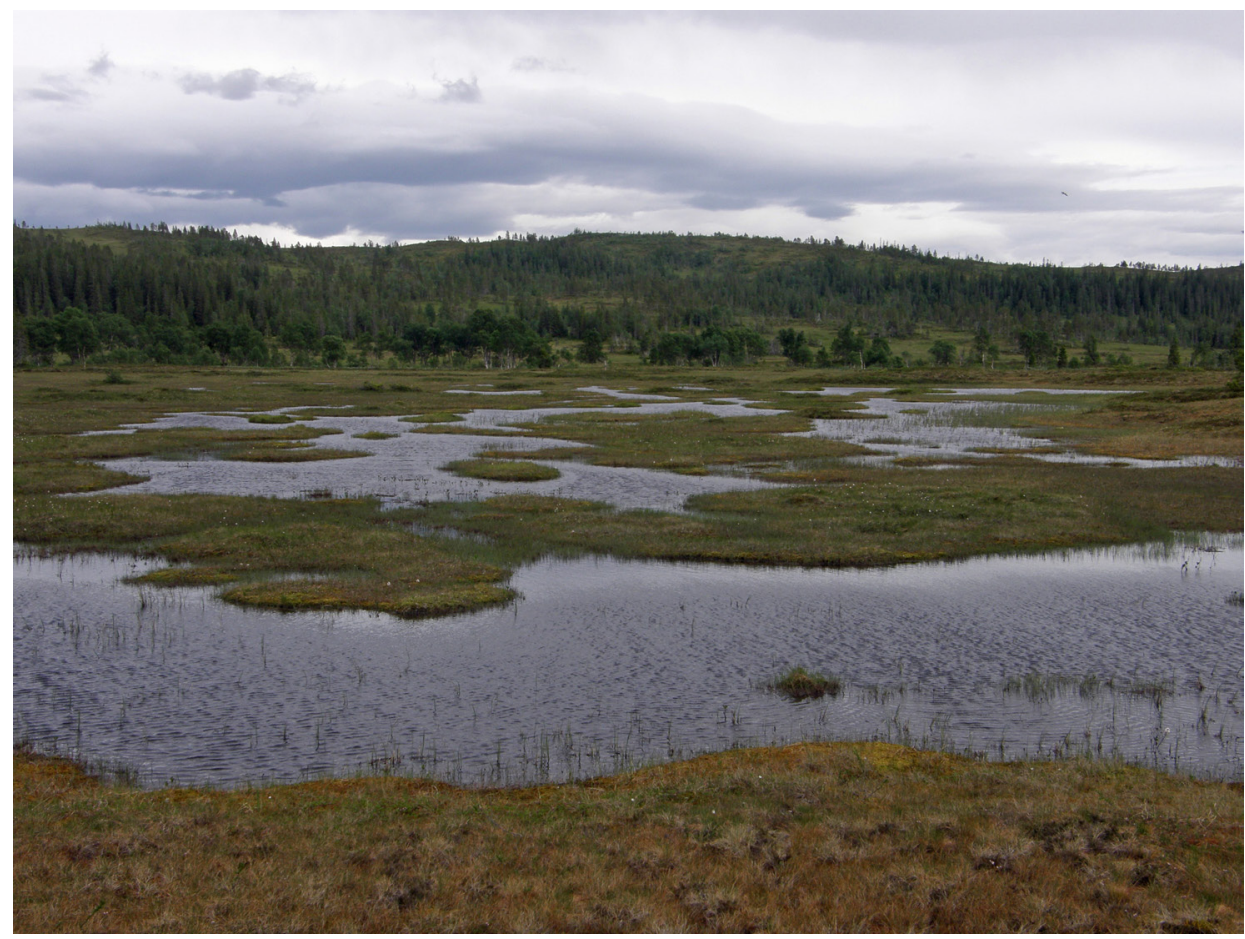

Figure 3. The upper part of the surveyed plot at Leinsslettene (cf. Figure 1). Photo: Per Gustav Thingstad.

did not occur in 2011 or 2012, while two species not recorded in 1971 or 1972, Great Snipe and Wood Sandpiper Tringa glareola, occurred in 2011 or 2012.

The category 'other species' (Table 1) includes two territories (nests) of Fieldfare Turdus pilaris found in 1971; in 2011 and 2012 also some other passerines associated with the surrounding forest habitats (Bluethroat Luscinia svecica, Common Redstart Phoenicurus phoenicurus, Redwing Turdus iliacus, Song Thrush Turdus philomelos and Hooded Crow Corvus cornix), and further a nesting Willow Grouse Lagopus lagopus, a Mallard Anas platyrhynchos

Table 1. Number of territories of the 16 most abundant bird species in the surveyed plots in 1971, 1972 (Moksnes 1977) and 2011, 2012. The waders and then the passerines are listed according to their total abundance over the four years.

\begin{tabular}{lrrrr}
\hline Species & 1971 & 1972 & 2011 & 2012 \\
\hline Common Redshank Tringa totanus & 7.50 & 8.50 & 12.00 & 13.25 \\
European Golden Plover Pluvialis apricaria & 9.00 & 7.00 & 6.50 & 4.75 \\
Whimbrel Numenius phaepus & 3.50 & 4.50 & 2.50 & 5.50 \\
Common Snipe Gallinago gallinago & 4.50 & 3.50 & 1.75 & 6.00 \\
Common Greenshank Tringa nebularia & 0.00 & 1.00 & 3.00 & 1.00 \\
Ruff Calidris pugnax & 3.00 & 2.00 & 0.00 & 0.00 \\
Common Sandpiper Actitis hypoleucos & 2.00 & 1.00 & 1.00 & 0.50 \\
Northern Lapwing Vanellus vanellus & 2.00 & 1.50 & 0.00 & 0.00 \\
Great Snipe Gallinago media & 0.00 & 0.00 & 2.00 & 0.00 \\
Wood Sandpiper Tringa glareola & 0.00 & 0.00 & 0.00 & 0.50 \\
Common Gull Larus canus & 0.00 & 1.00 & 4.00 & 4.50 \\
Meadow Pipit Anthus pratensis & 17.50 & 10.50 & 6.50 & 6.75 \\
Common Reed Bunting Emberiza schoeniclus & 3.50 & 4.00 & 2.00 & 0.50 \\
Willow Warbler Phylloscopus trochilus & 4.00 & 0.50 & 1.25 & 0.50 \\
Yellow Wagtail Motacilla flava & 1.50 & 0.00 & 1.00 & 3.00 \\
Brambling Fringilla montifringilla & 0.00 & 1.50 & 1.00 & 1.00 \\
Other species & 2.00 & 0.00 & 2.75 & 5.25 \\
Total number of territories & 60.00 & 46.50 & 47.25 & 53.00 \\
Territories of waders & 31.50 & 29.00 & 28.75 & 31.50 \\
\hline
\end{tabular}


territory and some fractions of a Red-throated Diver Gavia stellata and a Common Crane Grus grus territory.

\section{DISCUSSION}

The composition of the avifauna in the study plots shows striking similarity between the two dyads, both in species composition and in the numerical representation of a predominance of the species. The study does not reveal any significant population changes over the forty years between the dyads. This might primarily be attributable to the overall low sample size for most of the species involved. Partly because of this, variation within the dyads can also easily exceed the difference between the dyads. Such turned out to be the case even in the more numerous Meadow Pipit, indicating a substantial annual fluctuation of this species in the studied area. However, the mean number of registered territories of this pipit is today only half of what it was 40 years ago.

Surveys of breeding wader fauna on bogs rarely result in huge amounts of data, as their territories are very dispersed and large. As such, even large changes in population sizes might be recorded as insignificant within small monitoring areas. Accordingly, our barely one $\mathrm{km}^{2}$ surveyed bog areas included too few territories of less dominant species that one could expect to detect significant population changes. The only approach to detect population changes for such dispersed and lownumbered species is to compare their trends over a longer period from a sufficient number of locations.

In Øvre Forra the total numbers of territorial waders have varied remarkably little since the 1970 s, however, some of the involved species might indicate changes. The Common Redshank and the Common Greenshank Tringa nebularia both tended towards an increase since the 1970s. From the nearby mountain wetlands at Ånnsjön in Sweden, the Common Redshank is reported to be the most numerous wader (Holmberg 2012), and from the large-scale monitoring of breeding waders in the boreal and arctic regions of Fennoscandia since 2002 the species has shown significant positive trends (Lindström et al. 2015). Overall, population trends seem to be stable in the Common Greenshank yet slightly declining in the Common Redshank (Birdlife International 2015, Wetlands International 2015). Where population decreases are reported, habitat changes are often assumed to be the main cause, as for the lowland populations of the Common Redshank. There is no apparent change in the breeding habitat in the Øvre Forra reserve during the 40-year period of my study.

In contrast to the southern populations of the European Golden Plover that has declined, Fennoscandian populations are considered stable (Wetlands International 2006, Ottwall et al. 2009,
Väisänen et al. 2011, Grund 2014, Green \& Lindström 2015, Lindström et al. 2015), or even locally increasing (Svensson \& Andersson 2013), although the quality of data is poor (Wetlands International 2015). The longterm status for the Norwegian populations is unknown, and the negative tendencies seen in Øvre Forra and at Hardangervidda (Byrkjedal \& Kålås 2012) are too small for conclusion.

In spite of considerable recent decline in the Common Snipe Gallinago gallinago at the boreal and arctic breeding grounds in northern Fennoscandia (Lindström et al. 2015) and an apparent overall decline in Whimbrel (Henriksen \& Hilmo 2015), no decline was indicated at Øvre Forra for these species. Recently a significant decline is reported for the Common Snipe at the boreal and arctic breeding grounds in northern Fennoscandia (Lindström et al. 2015).

During the whole survey period, Great Snipe, still listed as near threatened NT by the most recent Norwegian Red List (Henriksen \& Hilmo 2015), displayed on a medium-sized lek near the Leinsslettene survey plot, yet only in one year (2011) were the criteria for territorial birds within this plot fulfilled (see method). According to Østnes \& Kroglund (2010), two Great Snipe leks in these parts of Øvre Forra have been known for more than 40 years, and numbers attending have been stable.

Very few pairs of the Common Sandpiper Actitis hypoleucos occurred within the survey plots and thus the observed lower numbers might only be coincidental. According to Wetlands International (2015), the West and Central European populations have declined between 1998 and 2008, although the quality of the information is poor. In Norway the species had a stable population for the period 1996-2013 (Kålås et al. 2014), while Husby \& Stueflotten (2009) found a decline in the period 1995-2008. In Sweden a significant decline is reported for the period 1975-2014, and a modest, insignificant decline for the period 1998-2014 (Green \& Lindström 2015).

The disappearance of the Ruff and the Northern Lapwing from the Øvre Forra area is in accordance with the global decrease in these species (Birdlife International 2015), a decrease found for both species also in Fennoscandia (Väisänen et al. 2011, Svensson \& Andersson 2013, Grund 2014, Heggøy \& Øyen 2014, Østnes \& Kroglund 2014). Both are listed in the new Norwegian Red List (Henriksen \& Hilmo 2015) as endangered (EN). In Nord-Trøndelag, the Ruff was a quite common breeder in the 1970s and 1980s, but has since disappeared from most of its traditional lekking areas, even where the habitat quality has remained unchanged (Østnes \& Kroglund 2014). At Holmtjønna in Øvre Forra, a maximum of 23 lekking males was registered by 1968 (Moksnes 1971), whereas the last single male was seen in 2000 (Thingstad 2012). In the important wetland area nearby in Sweden, Annsjön, the 
Ruff has shown the same negative trend since the middle of the 1990s, although there have been indication lately of some increase (Holmberg 2012).

The present low number of Meadow Pipit on the Øvre Forra's bogs may indicate a decrease, yet the numbers are inconclusive. A decrease in Meadow Pipit numbers was registered on Hardangervidda between 1980 and 2010/11 (Byrkjedal \& Kålås 2012), and it has shown a negative trend during the last 40 years at two bogs in Aurskog-Høland (Hardeng 2014). At Ammarnäs in Swedish Lapland, Svensson \& Andersson (2013) registered a decrease since the early 2000s up to 2010 and the species is now at a low at the marshes of Dalarna (Grund 2014).

The observed possible decline in the Common Reed Bunting Emberiza schoeniclus is consistent with the 30-year trend for the Swedish populations (Ottvall et al. 2009), but Svensson \& Andersson (2013) suggested that habitat deterioration in southern Sweden might be the main cause of the Swedish decline. From some surveyed marshes in Dalarna the Common Reed Bunting population seemed to be at the same level in 2012 as it was in 1977-79 (Grund 2014). In Norway the Common Reed Bunting is now listed as near threatened (NT) in the new Red List (Henriksen \& Hilmo 2015).

The study area was environmentally stable during the 40-year study period with no apparent changes to the habitat conditions on the breeding grounds. All things considered, the avifauna has also remained noteworthy unaltered over this period. This prevailing stability makes the reserve the more valuable as a breeding bird resort, especially for waders, which make up a prominent part of the species composition.

Acknowledgements. I am grateful to Arne Moksnes who introduced me to bird population surveying at Nedalen in 1973. Moksnes was also responsible for the ornithological investigation in Øvre Forra in 1970-1972, which represents the required background material for our work conducted here four decades later. I would like to thank Geir E. Vie and Tom Roger Østerås for their assistance during the field work in 2011 and 2012, and Adriaan de Jong and Rob Barrett for many constructive comments, the latter also for improving my English. I also thank Marc Daverdin for drawing the map in Figure 1. The Directorate of Nature Management (currently the Norwegian Environment Agency) funded the present bird surveys through their project 'Follow-up of conservation areas - conservation aims and monitoring'.

\section{REFERENCES}

Bibby, C.J., Burness, N.D. \& Hill, D.A. 1992. Bird census techniques. Academic Press, London.

BirdLife International. 2004. Birds in Europe: population estimates, trends and conservation status. BirdLife International, Cambridge.

BirdLife International. 2015. IUCN Red List for birds. http:// www.birdlife.org on 02/2015.
Byrkjedal, I. \& Kålås, J.A. 2012. Censuses of breeding birds in a South Norwegian arctic-alpine habitat three decades apart show population declines in the most common species. Ornis Norvegica 35: 43-47.

Enemar, A., Sjöstrand, B., Andersson, G., \& Von-Proschwitz, T. 2004. The 37-year dynamics of a subalpine passerine bird community, with special emphasis on the influence of environmental temperature and Epirrita autumnata cycles. Ornis Svecica 14: 63-106.

Foppen, R. \& Riejnen, R. 1996. The willow warbler Phylloscopus trochilus in trouble: Africa involved? Limosa 69: 51-56.

Fowler, J. \& Cohen, L. 1990. Practical statistics for field biology. John Wiley \& Sons, Chichester.

Green, M. \& Lindström, Å. 2015. Övervakning av fåglarnas populationsutveckling. Årsrapport för 2014. Rapport, Biol. inst., Lunds Universitet: 1-86. (In Swedish with English summary)

Grund, L.-O. 2014. Myrfågelinventering i Älvdalens kommun under perioden 1977 til 2012. Länsstyrelsen Dalarne län Rapport 2014 (03). (In Swedish)

Hardeng, G. 2014. Fuglefaunaen på myrene Midtfjellmosen og Store Rekke i Aurskog-Høland, Akershus, i 197577 og i 2014. Fauna 67: 118-131. (In Norwegian with English summary)

Heggøy, O. \& Øien, I.J. 2014. Vipa går en usikker framtid i møte. Vår Fuglefauna 37: 114-127. (In Norwegian with English summary)

Henriksen S. \& Hilmo O. (eds.) 2015. Norsk rødliste for arter 2015. Artsdatabanken, Norge. (In Norwegian with English summary)

Hogstad, O. 2005. Numerical and functional responses of breeding passerine species to mass occurrence of geometrid caterpillars in a subalpine birch forest: A 30-year study. Ibis 147: 77-91.

Holmberg, T. 2012. Myrinventeringen. Fåglar i JämtlandHärjedalen 32 (4): 9-11. (In Swedish)

Husby, M. \& Stueflotten, S. 2009. Norsk hekkefugltaksering. Bestandsutvikling i HTF-områder for 57 arter 19952008. NOF Rapport 2009-6: 1-29 + vedlegg. (In Norwegian)

Kålås, J.A., Husby, M., Nilsen, E.B. \& Vang, R. 2014. Bestandsvariasjoner for terrestriske fugler i Norge 1996 2013. NOF Rapport 2014-4: 1-36. (In Norwegian)

Ławicki, Ł., Wylegała, P., Batycki, A., Kajzer, Z., Guentzel, S., Jasiński, M., Kruszyk, R., Rubacha, S. \& Żmihorski, M. 2011. Long-term decline of grassland waders in western Poland. Vogelwelt 132: 101-108.

Lindström, Å., Green, M., Husby, M., Kålås, J.A. \& Lehikoinen, A. 2015. Large-scale monitoring of waders on their boreal and arctic breeding grounds in northern Europe. Ardea 103: 3-15.

Moen, A., Kjelvik, L., Bretten, S., Sivertsen, S. \& Sæther, B. 1976. Vegetasjon og flora i Øvre Forradalsområdet i Nord-Trøndelag, med vegetasjonskart. K. norske Vidensk. Selsk. Mus. Rapport Bot. Ser.1976-9: 1-135 +2 pl. (In Norwegian) 
Moksnes, A. 1971. Ornitologiske undersøkelser i reguleringsområdet for de planlagte Forraverkene. Rapport Zool. inst., UNIT: 1-27. (In Norwegian)

Moksnes, A. 1973. Quantitative surveys of the breeding bird populations in some subalpine and alpine habitats in the Nedal area in Central Norway (1967-71). Norwegian Journal of Zoology 21: 113-118.

Moksnes, A. 1977. Fuglefaunaen i Forraområdet i NordTrøndelag. Sluttrapport undersøkelsene 1970-72. K. norske Vidensk. Selsk. Mus. Rapport Zool. Ser.1977-3: 1-56. (In Norwegian)

Ottvall, R., Edenius, L., Elmberg, J., Engström, H., Green, M., Holmqvist, N., Lindström, Å., Pärt, T. \& Tjernberg, M. 2009. Population trends for Swedish breeding birds. Ornis Svecica 19: 117-192.

Peach, W., Baillie, S. \& Underhill, L. 1991. Survival of British Sedge Warbler Acrocephalus schoenobaenus in relation to West African rainfall. Ibis 133: 300-305.

Svensson, S. 1978. Förenklad revirkarteringsmetod för inventering av fåglar på myrar och mossar. Vår Fågelvärld 37: 9-18. (In Swedish with English summary)

Svensson, S. \& Andersson, T. 2013. Population trends of birds in alpine habitats at Ammarnäs in southern Swedish Lapland 1972-2011. Ornis Svecica 23: 81-107.

Thingstad, P.G. 2012. Oppfølging av verneområder: Status for fuglesamfunnet på myr i Øvre Forra naturreservat, Nord-Trøndelag. NTNU Vitenskapsmuseet Rapport Zoologisk serie 2012-2. (In Norwegian with English summary)
Thingstad, P.G., Hogstad, O. \& Speed, J.D.M. 2015. The influence of climatic conditions in breeding grounds and migratory flyways on a subalpine Norwegian Willow Warbler Phylloscopus trochilus population. Ornis Fennica 92: 23-33.

Tucker, G.M. \& Heath, M.F. 1994. Birds in Europe: their conservation status. BirdLife International, Cambridge.

Väisänen, R.A., Hario, M. \& Saurola, P. 2011. Population estimates of Finnish birds. In: Valkama, J., Vepsäläinen, V. \& Lehikoinen, A. (eds.). The Third Finnish Breeding Bird Atlas. Finnish Museum of Natural History and Ministry of Environment. http://atlas3.lintuatlas.fi/ english ; ISBN 978-952-10-7145-4.

Wetlands International 2006. Waterbird Population Estimates. Fourth Edition. Wetlands International, Wageningen.

Wetlands International 2015. Waterbird Population Estimates. Retrieved from: wpe.wetlands.org. 10 Mar 2015.

Zwarts, L., Bijlsma, R.G., van der Kamp, J. \& Wymenga, E. 2010. Living on the edge: Wetlands and birds in a changing Sahel. 2nd ed. KNNV Publ., Zeist.

Østnes, J.E. \& Kroglund, R.T. 2010. Kartlegging av spillplasser for dobbeltbekkasin (Gallinago media) i Nord-Trøndelag. Høgskolen i Nord-Trøndelag. Utredning 116. (In Norwegian with English abstract)

Østnes, J.E. \& Kroglund, R.T. 2014. Bestandsstatus for brushane (Philomachus pugnax) i Nord-Trøndelag. Høgskolen i Nord-Trøndelag. Utredning 160. (In Norwegian with English abstract)

Received 20 April 2015. Accepted 1 December 2015 